\title{
Hubungan antara Berat Badan Berlebih dengan Terjadinya Sindrom Syok Dengue pada Anak di RSD dr. Soebandi, Jember
}

\section{(The Relationship between Overweight and the Occurence of Dengue Shock Syndrome in Children at dr. Soebandi Hospital, Jember)}

\author{
Hana Nabilah, M. Ali Shadikin, Rony Prasetyo \\ Fakultas Kedokteran Universitas Jember \\ Jl. Kalimantan 37 Kampus Tegal Boto Jember 68121 \\ e-mail: alipspd@unej.ac.id
}

\begin{abstract}
Dengue Shock Syndrome (DSS) is shock syndrome that happened in dengue hemorrhagic fever patients. There are risk factors that cause DSS. One of them is overweight in children. This study aimed to determine the relationship between overweight and the occurence of DSS. This retrospective case control study conducted at the dr. Soebandi Hospital Jember. Sampels were divided into DSS group (case group) and non-DSS group (control group). To analyze the data, Chi-Square test was performed using SPSS version 21. Aa many as 191 patients were included in this study which consisted of 132 patients as the control group and 59 patients as the case group. Chi-square analysis showed the p-value was 0,649. In conclusion, overweight was not significantly associated as a risk factor of DSS in children at the dr. Soebandi hospital.
\end{abstract}

Keywords: Children, Dengue Shock Syndrome, Overweight

\begin{abstract}
Abstrak
Sindrom Syok Dengue (SSD) adalah sindrom syok yang terjadi pada penderita demam berdarah dengue. Terdapat beberapa faktor yang dapat menyebabkan SSD. Salah satunya adalah berat badan berlebih pada anak. Penelitian ini bertujuan untuk mengetahui hubungan antara berat badan berlebih dengan kejadian SSD pada anak. Penelitian retrospektif case contro/ini dilakukan di RSD dr. Soebandi Jember. Sampel dibagi menjadi dua kelompok yaitu $S S D$ (kelompok kasus) dan kelompok non-SSD (kelompok kontrol). Analisis data dilakukan dengan uji Chi-Square menggunakan SPSS versi 21. Terdapat 191 pasien anak yang memenuhi kriteria sampel dalam penelitian ini yang terbagi menjadi 132 pasien kelompok kontrol dan 59 pasien kelompok kasus. Dalam penelitian ini, didapatkan nilai $p$-value $=0,649$. Dapat disimpulkan bahwa berat badan berlebih tidak berhubungan secara signifikan terhadap kejadian Sindrom Syok Dengue pada pasien anak di RS dr. Soebandi.
\end{abstract}

Kata kunci: Anak, Sindrom Syok Dengue, Berat Badan Berlebih

\section{Pendahuluan}

Sindrom Syok Dengue (SSD) adalah

sindrom syok yang terjadi pada penderita

Demam Berdarah Dengue (DBD). Demam berdarah dengue adalah penyakit infeksi yang disebabkan oleh virus dengue yang ditularkan melalui gigitan nyamuk aedes aegepty dengan manifestasi klinis demam, nyeri otot, dan/atau 
nyeri sendi yang disertai leukopenia, ruam, limfadenopati, trombositopenia, perdarahan dan kebocoran plasma [1].

Penyakit ini merupakan salah satu penyakit yang menjadi masalah kesehatan masyarakat dan endemis di hampir seluruh kabupaten/ kota di Jawa Timur. Berdasarkan Laporan Program DBD Dinas Kesehatan Provinsi Jawa Timur diketahui bahwa terjadi peningkatan jumlah kasus DBD, yaitu dari tahun 2011 sebesar 5.374 penderita dengan jumlah kematian sebesar 65 orang dan meningkat menjadi 8.266 penderita dengan jumlah kematian sebesar 119 orang pada tahun 2012 [2]. Pada tahun 2013 telah terjadi KLB DBD di Kabupaten Jember. Terjadi peningkatan kasus pada periode waktu tiga tahun terakhir yaitu pada tahun 2011, 2012, 2013 secara berturutturut sebesar 77 penderita, 260 penderita, dan 1018 penderita [2].

Berat badan berlebih dicurigai menjadi faktor resiko terhadap kejadian SSD pada anak. Hal ini dikaitkan dengan teori bahwa jaringan adiposa tersusun atas sel adiposa dan kompartemen vaskular yang didalam selnya terdapat preadiposit dan makrofag. Jumlah adiposa meningkat seiring dengan penambahan jumlah sel adiposa melalui deposit lemak, diikuti penambahan jumlah sel-sel adiposit. Jaringan adiposa pada obesitas juga ditandai dengan peningkatan jumlah infiltrasi makrofag [3]. Makrofag memproduksi tiga sitokin pro-inflamasi yakni TNF- $\alpha$, Interleukin-1 (IL-1), dan Interleukin6 (IL-6) yang merupakan faktor utama pencetus terjadinya respon fase akut [4]. Sitokin dan mediator kimiawi tersebut menginduksi sel-sel endotel vaskular sehingga terjadi malfungsi endotel dan dapat menyebabkan peningkatan permeabilitas vaskular [5].

Beberapa penelitian mengenai hubungan antara berat badan berlebih dengan kejadian sindrom syok dengue telah dilakukan di berbagai negara, namun didapatkan hasil yang berbedabeda. Penelitian milik Thisyakorn dan Nimmannitya melaporkan malnutrisi kalori dan protein derajat ringan akan terhindar dari SSD [6]. Pichainarong et. al melaporkan pasien obesitas memiliki risiko menderita DBD derajat berat lebih tinggi [7]. Elmy et. al (2009) juga melaporkan bahwa obesitas merupakan faktor resiko terjadinya SSD pada anak [8]. Berbeda dengan penelitian di Yogyakarta oleh Sugiyanto et al. dan di Taiwan oleh Hung et. al didapatkan bahwa status gizi tidak mempengaruhi derajat berat ringannya penyakit DBD $[9,10]$. Penelitian Widiyati et. al tahun 2013 melaporkan bahwa obesitas bukan merupakan faktor resiko terjadinya SSD pada anak [11]. Begitu juga Ganda et.al di Makasar melaporkan tidak ada perbedaan status gizi antara kelompok DBD dan DBD dengan syok [12]. Tujuan penelitian ini adalah menganalisis hubungan antara Berat Badan Berlebih dengan Terjadinya Sindrom Syok Dengue pada Anak di RSD dr. Soebandi Jember.

\section{Metode Penelitian}

Penelitian ini menggunakan desain studi retrospektif case control. Penelitian dilakukan di RSD dr. Soebandi Jember dengan menggunakan data sekunder berupa rekam medis. Penelitian telah mendapatkan ijin etik dan Komisi Etik Penelitian Fakutas Kedokteran Universitas Jember. Teknik yang digunakan dalam pengambilan adalah total sampling. Sampel dalam penelitian ini adalah populasi semua anak yang mengalami DBD dan SSD dan tercatat di rekam medis RSD dr. Soebandi Jember periode Oktober 2013-Oktober 2016 yang memenuhi kriteria inklusi dan eksklusi. Kriteria inklusi dari penelitian ini adalah anak berusia 0-18 tahun yang mengalami DBD dan SSD. Kriteria Eksklusi dari penelitian ini adalah anak yang mengalami DBD dan SSD yang memiliki catatan medik yang tidak lengkap serta mengalami penyakit berat lain.

Sampel yang telah diperoleh akan dibagi menjadi dua kelompok yaitu kelompok anak berat berlebih (overweight dan obesitas) yang mengalami DBD dan SSD dan kelompok anak berat tidak berlebih (gizi normal dan kurang) yang mengalami DBD dan SSD. Setelah semua data sampel terkumpul, dilakukan analisis data dengan program Statistical Package for the Social Sciences (SPSS) 21.0. Analisis data dilakukan dalam dua tahap. Pertama, analisis univariat yang disajikan dalam bentuk distribusi frekuensi. Kedua, analisis uji statistik komparatif dengan uji Chi-Square.

\section{Hasil}

Hasil penelitian disajikan dalam bentuk tabel distribusi. Distribusi frekuensi jenis kelamin anak disajikan pada Tabel 1.

Tabel 1. Distribusi usia anak

\begin{tabular}{|l|c|c|}
\hline \multicolumn{1}{|c|}{ Usia } & $\begin{array}{c}\text { Jumlah Sampel } \\
\text { (Orang) }\end{array}$ & $\begin{array}{c}\text { Persentase } \\
(\%)\end{array}$ \\
\hline 0-5 tahun & 60 & 31,4 \\
\hline 6-10 tahun & 74 & 38,8 \\
\hline 11-15 tahun & 54 & 28,2 \\
\hline
\end{tabular}




\begin{tabular}{|c|c|c|}
\hline $16-18$ tahun & 3 & 1,6 \\
\hline Jumlah & 191 & 100 \\
\hline
\end{tabular}

Distribusi jenis kelamin anak pada penelitian ini disajikan pada Tabel 2.

Tabel 2. Distribusi jenis kelamin

\begin{tabular}{|c|c|c|}
\hline Jenis Kelamin & $\begin{array}{c}\text { Jumlah Sampel } \\
\text { (orang) }\end{array}$ & $\begin{array}{c}\text { Persentase } \\
(\%)\end{array}$ \\
\hline Laki-laki & 89 & 46,6 \\
\hline Perempuan & 102 & 53,4 \\
\hline Jumlah & 191 & 100 \\
\hline
\end{tabular}

Distribusi status gizi terhadap derajat penyakit dalam penelitian disajikan pada Tabel 3.

Tabel 3. Distribusi status gizi terhadap derajat penyakit

\begin{tabular}{|l|c|c|c|c|}
\hline \multirow{2}{*}{$\begin{array}{l}\text { Status } \\
\text { Gizi }\end{array}$} & \multicolumn{4}{|c|}{ Derajat Penyakit } \\
\cline { 2 - 5 } & $\begin{array}{c}\text { non-SSD } \\
\text { Jumlah } \\
\text { (orang) }\end{array}$ & $\begin{array}{c}\text { Persent } \\
\text { ase } \\
\text { (\%) }\end{array}$ & $\begin{array}{c}\text { Jumlah } \\
\text { (orang) }\end{array}$ & $\begin{array}{l}\text { Persent } \\
\text { ase } \\
(\%)\end{array}$ \\
\hline $\begin{array}{l}\text { Berat } \\
\text { Berlebih }\end{array}$ & 19 & 65,5 & 10 & 34,5 \\
\hline $\begin{array}{l}\text { Tidak } \\
\text { Berlebih }\end{array}$ & 113 & 34,5 & 49 & 65,5 \\
\hline Total & 132 & & 59 & \\
\hline
\end{tabular}

Untuk mengetahui hubungan berat berlebih dengan kejadian SSD pada anak di RSD dr. Soebandi Kabupaten Jember, sampel akan dianalisis dengan Uji nonparametrik ChiSquare $\left(\mathrm{X}^{2}\right)$. Hasil analisis dan nilai confidence intervalakan disajikan pada Tabel 4.

Tabel 4. Uji Chi-Square dan IK

\begin{tabular}{|c|c|}
\hline & $p$-value \\
\hline Chi-Square Test & 0,65 \\
\hline IK (95\%) & $0,526-2,8$ \\
\hline $\mathrm{N}$ & 191 \\
\hline \multicolumn{2}{|c|}{ *signifikan $(\mathrm{p}<0,05)$} \\
\hline
\end{tabular}

\section{Pembahasan}

Hasil penelitian menunjukkan bahwa distribusi usia anak yang menjadi sampel penelitian terbanyak pada rentang usia anak sekolah yakni 6-10 tahun, sedangkan rentang usia dengan jumlah paling sedikit adalah usia 1618 tahun. Hal ini sejalan dengan penelitian milik Dardjito et. al yang menyatakan anak usia $<12$ tahun lebih banyak terinfeksi virus dengue dikarenakan lebih sering beraktivitas didalam rumah atau ruangan tertutup [13]. Data milik Dinas Kesehatan Yogyakarta (2010) menunjukkan bahwa $66 \%$ penderita DBD terjadi pada anak-anak dengan usia kurang dari 15 tahun. Kelompok umur tersebut lebih rentan terkena DBD karena faktor daya tahan tubuh yang rendah. Kelompok umur $<12$ tahun memiliki daya tahan tubuh yang rendah dibandingkan kelompok umur yang lebih tua, serta aktivitasnya yang sering bermain atau sekolah dapat meningkatkan resiko terkena gigitan nyamuk DBD karena kondisi dan waktu tertentu [14].

Hasil penelitian menunjukkan jumlah anak laki-laki sebanyak 89 orang dan perempuan 102 orang. Dari data tersebut diketahui bahwa sampel didominasi oleh jenis kelamin perempuan $(53,4 \%)$. Hal ini sejalan dengan penelitian milik Vicente et. al (2013) yang mendapatkan kasus infeksi dengue terbanyak pada jenis kelamin perempuan [15]. Berbeda dengan penelitian milik Hung et. al (2005) dan Pothapregada et. al (2015) yang mendapatkan pasien DBD terbanyak adalah laki-laki $[10,16]$. Akan tetapi, beberapa penelitian seperti milik Elmy et. al (2009), Blanton et. al (2008), dan Tee et. al (2009) menyebutkan bahwa tidak terdapat perbedaan yang signifikan mengenai jenis kelamin dengan jumlah kasus infeksi dengue $[8,17,18]$.

Hasil analisis dengan uji Chi-Square didapatkan hasil $p=0,649$ yang berarti secara statistik tidak terdapat hubungan yang signifikan antara berat badan berlebih dengan kejadian SSD pada anak.

Hasil analisis penelitian ini tidak sejalan dengan beberapa penelitian lain sebelumnya, dimana didapatkan bahwa terdapat hubungan antara anak dengan berat badan berlebih dengan kejadian SSD dimana anak obesitas mempunyai resiko terkena SSD 4,9 kali lebih besar daripada anak non-obese [8]. Halstead (1997) mengatakan bahwa anak-anak dengan malnutrisi punya resiko yang lebih kecil terhadap derajat infeksi DBD/SSD dikarenakan mereka mempunyai respon selular imun yang lebih sedikit dibandingkan anak dengan obesitas [19]. Begitu pula dengan penelitian milik Pichainarong et al. (2006) yang menggunakan jenis desain studi case control dengan jumlah sampel 105 untuk masing-masing kelompok menyatakan bahwa pasien dengan obesitas memiliki resiko yang lebih besar dibandingkan pasien dengan berat badan normal dengan $p=0,001$ [7].

Hasil penelitian ini sejalan dengan 
penelitian milik Maron et al. (2010) yang tidak menemukan korelasi antara berat badan normal maupun berlebih dengan derajat keparahan infeksi dengue [20]. Penelitian yang dilakukan oleh Trang et al. (2016) juga menunjukkan bahwa tidak terdapat hubungan yang signifikan pada anak overweightlobesitas dengan SSD [21]. Obesitas adalah penyakit kronik dengan tingkat inflamasi rendah dengan produksi IL-1ß, IL-6 dan TNF- $\alpha$ yang berlebih [22]. Paparan kronis terhadap sitokin pro-inflamasi dapat mengurangi sensitivitas sel imun tubuh saat respon inflamasi selama infeksi berlangsung [23]. Hasil yang serupa juga dikemukakan oleh Hung et al. (2005) yang menyatakan bahwa kadar level serum sitokin (IFN- $\gamma$, TNF- $\alpha$, IL-10 dan IL-6) dan antibodi virus dengue pada anak tidak dipengaruhi oleh status nutrisi. Produksi sitokin dan antibodi virus dengue tidak berbeda antara jenis kelamin dan anak dengan malnutrisi atau tidak [10]. Penelitian milik Widiyati et al. (2013) menyatakan pula bahwa obesitas bukan merupakan faktor resiko terjadinya SSD dengan $p=0,07 \quad$ [11]. Kalayanarooj (2005) juga melaporkan dalam penelitiannya yang melibatkan 4532 kasus yang dimana $30.6 \%$ menjadi syok. Kebanyakan dari mereka punya status gizi normal $(66,6 \%)$, malnutrisi $(9,3 \%)$ and gizi lebih $(24,2 \%)$. Pasien malnutrisi memiliki risiko lebih tinggi terkena syok $(37,8 \%)$ daripada pasien normal $(29,9 \%)$ dan pasien obesitas $(30,2 \%)(p=0,000)$. Pasien obesitas memiliki presentasi resiko komplikasi ensefalopati $(1,3 \%)$ dan infeksi yang terkait (4.8\%), daripada pasien normal $(0,5 \%$ dan $2,7 \%)$ dan pasien malnutrisi (1,2\% dan 3,1\%) [24].

Adanya hubungan yang tidak signifikan antara berat badan berlebih dengan kejadian SSD pada penelitian ini dapat dipengaruhi oleh beberapa faktor diantaranya adalah pengukuran lemak tubuh pada anak, dimana pada penelitian ini menggunakan indikator $\mathrm{BB} / \mathrm{U}$ yang kurang sensitif untuk mengukur lemak tubuh secara langsung. Pengukuran lemak tubuh lebih disarankan menggunakan parameter skinfoldthickness karena lebih merepresentasikan komposisi tubuh. Parameter BB/U merefleksikan weight-for-height maupun height-for-age namun tidak dapat membedakan anak yang tinggi-kurus dengan anak yang pendek-normal [25]. Penggunaan parameter BB/U juga harus menggunakan umur pasien yang dihitung dari hari kelahiran yakni tahun dan bulan, namun dalam data rekam medis penelitian ini, usia hanya ditulis dalam tahun saja.
Faktor sosial-ekonomi juga ikut berpengaruh dalam output hasil penelitian ini. Seperti dikatakan Maron et al. (2016) dalam penelitiannya yang meneliti masalah sosialekonomi pasien DBD diantaranya berupa lingkungan tempat tinggal, pendidikan, pekerjaan, dan penghasilan [20]. Penelitian milik Kesetyaningsih et al. (2016) di Yogyakarta juga menyatakan bahwa tingkat wawasan dan perilaku masyarakat juga berpengaruh secara signifikan terhadap tingkat keparahan penyakit [26]. Menurut Vicente et al. (2013) yang melakukan penelitian di Brazil, penanganan awal yang memadai dan penanganan yang baik dari penyedia layanan kesehatan juga dapat menghasilkan prognosis penyakit yang lebih baik [15].

\section{Simpulan dan Saran}

Kesimpulan pada penelitian ini tidak terdapat hubungan yang signifikan antara berat badan berlebih pada anak dengan kejadian Sindrom Syok Dengue.

Diharapkan masyarakat umum khususnya orang tua agar dapat meningkatkan pengetahuan tentang penanganan awal pada anak yang memiliki tanda-tanda DBD.

\section{Daftar Pustaka}

[1] Suhendro, Nainggolan L., Chen K, Pohan HT. Demam Berdarah Dengue. Dalam Buku Ajar IImu Penyakit Dalam. Editor A.W. Sudoyo, B. Setiyohadi, I. Alwi, M. Simadibrata, S. Setiati. Jakarta: InternaPublishing; 2009.

[2] Dinas Kesehatan Provinsi Jawa Timur [Internet]. Profil Kesehatan Provinsi Jawa Timur; 2013. [cited 2016 October 4] Available from http://dinkes.jatimprov.go.id.

[3] Flier JS, Maratos-Flier, E. Biology of Obesity. Dalam Harrison's Principles of Internal Medicine. Editor A.S Fauci, D.L Kasper, D.L Longo, E. Braunwald, S.L Hauser, J.L Jameson, J. Loscalzo. America: McGraw-Hill; 2008.

[4] Louise, Mary. Immunology and Serology in Laboratory Medicine. Second Edition. America: Mosby; 1996.

[5] Rajapakse, Senaka. Dengue Shock. J Emerg Trauma Shock. 2011 Jan-Mar; 4(1): 120-127.

[6] Thisyakorn U, Nimmannitya S. Nutritional status of children with dengue hemorrhagic fever. Clin Infect Dis 1993;16:295-7. 
[7] Pichainarong N, Mongkalangoon N, Katayanarooj S. Chaveepojnkamjorn W. Relationship between body size and severity of dengue hemorrhagic fever among children aged 0-14 years. Southlast Asian J Trop Med Public Health 2006;3:2838.

[8] Elmy S, Arhana BNP, Suandi IKG, Sidiartha IGL. Obesitas Sebagai Faktor Risiko Sindrom Syok Dengue. Jurnal Sari Pediatri. 2009 Vol. 11, No. 4.

[9] Sutaryo. Dengue. Yogyakarta: Medika Fakultas kedokteran Universitas Gadjah Mada; 2004.

[10] Hung NT, Lan NT, Lei HY, Lin YS, Lein LB, Huang KJ. Association between sex, nutritional status, severity of dengue hemorrhagic fever, and immune status in infants with dengue hemorragic fever. Am J Trop Med Hyg 2005 vol 72:370-4.

[11] Widiyawati MMT, Laksanawati IS, Prawirohartono EP. Obesity as a Risk Factor for Dengue Shock Syndrome in Children. Jurnal Paediatrica Indonesiana. 2013 vol. 53, no. 4.

[12] Ganda IJ, Boko SH, Daud D. Comparison of blood gases analysis in patient with dengue shock syndrome and dengue hemorrhagic fever. J Med Nus 2006;27:151-5.

[13] Dardjito E, Yuniarno S, Wibowo C, Saptaprasetya DL, Dwiyanti H. Beberapa Faktor Risiko yang Berpengaruh terhadap Kejadian Penyakit Demam Berdarah Dengue (DBD) di Kabupaten Banyumas. Media Litbang Kesehatan 2008 Vol XVIII no 3 (126-136).

[14] WHO. Dengue: Guidelines for Diagnosis, Treatment, Prevention and Control. Geneva: WHO; 2009.

[15] Vicente CR, Lauar JC, Santos BS, Cobe VM, Junior CC. Factors related to severe dengue during an epidemic in Vitoria, State of Espirito Santo, Brazil. Revista de Sociedade Brasileira de Medicina Tropical. 2013 vol 46(5):629-632.

[16] Pothapregada S, Kamalakannan B, Thulasingham $M$. Risk factors for shock in children with dengue fever. Indian Journal of
Critical Care Medicine. 2015 vol 19:661-664.

[17] Blanton RE, Silva LK, Morato VG, Parrado AR, Dias JP. Genetic ancestry and income are associated with dengue hemorrhagic fever in a highly admixed population. Eur $\mathrm{J}$ Human Genetics. 2008 vol. 16:762-765.

[18] Tee HP, How SH, Jamalludin AR, Safhan MNF, Sapian MM, Kuan YC, Sapari S. Risk factors associated with development of dengue haemorrhagic fever or dengue shock syndrome in adults in hospital Tengku Ampuan Afzan Kuantan. Medical Journal Malaysia. 2009 vol. 64(4).

[19] Halstead, SB. Epidemiology of dengue and dengue hemorrhagic fever. In Gubler DJ, kuno $G$, eds. Dengue and dengue hemorrhagic fever. Wallingford, New York: CAB International; 1997.

[20] Marón GM, Clara AW, Diddle JW, Pleites EB, Miller L, MacDonald G, Adderson EE. Association between nutritional status and severity of dengue infection in children in El Salvador. American J Tropical Medicine and Hygiene. 2010 vol 82(2): 324-329.

[21] Trang NTH, Long NP, Hue TTM, Hung LP, Trung TD, Dinh DN, Luan NT, Huy NT, Hirayama K. Association between nutritional status and dengue infection: a systematic review and meta-analysis. BMC Infectious Diseases. 2016 vol 16:172.

[22] Marti A, Marcos A, Martinez JA. Obesity and immune function relationships. Obes Rev. 2001 vol 2(2): 131-40.

[23] Milner JJ, Beck MA. The impact of obesity on the immune response to infection. Proc Nutr Soc. 2012 vol 71: 298-302.

[24] Kalayanarooj S, Nimmannitya S. Is dengue severity related to nutritional status?. Southeast Asian J Trop Med Public Health. 2005 vol 36: 378-384.

[25] Gibson RS. Principles of Nutritional Assessment. Second Edition. New York: Oxford University Press; 2005.

[26] Kesetyaningsih TW, Ulfabriana A. Knowledge, behaviour and socio-economic status of community in dengue endemic areas with increase and stable trends in Sleman District, Yogyakarta, Indonesia. AIP Conference Proceeding. 2016 vol. 1744. 